\title{
The Evaluation of Road Safety Programs District Level at Banyumas and Pasuruan
}

\author{
Bambang Istiyanto
}

\begin{abstract}
Sustainable development Goal serves as a guideline for the implementation of regency/city government in Indonesia. One of the indicators is the reduction in the number of deaths caused by traffic accidents. With a five-pillar safety instrument from the decade of action for road safety, data collection is conducted to determine the implementation of the program. The results of the data collection show the success of the action programs conducted by Government of Banyumas and Pasuruan Regency. Furthermore, we can find out that the program of five pillars can be implemented in the districts. The analysis is done by collecting programs and actions from each pillar. It is then given a value; if the action is executed the value given is 1 and the non-executed action is 0 , and ultimately it is calculated in a percentage indicating the performance of each pillar. The index is based on both a content analysis approach and a binary methodology (report/no report) with only the items, which have been considered pertinent and not redundant. The five pillars are safety management system, safer roads, safer vehicle, safer road users and post-crash response.
\end{abstract}

Index Terms - Road Traffic Safety Programs (RTSP), five-pillar safety instrument, traffic accident.

\section{INTRODUCTION}

T raffic accidents in Indonesia in the Year 2017 amounted to 102,049 with the death toll as many as 25,452 inhabitants. When compared to the base year of road safety decade in 2010, an increase of accident incident equals to $53,48 \%$ and death victims equal to $27,39 \%$. The number of traffic accidents in the year 2010 amounted to 66,488 and the death toll of 19,979 inhabitants. The year 2017 is the 7 th year after the declaration decade of action for road safety, from the data it can be seen that the safety action programs undertaken by the government, provincial and district/city governments have not achieved maximum results. The Government of Indonesia declared this program since 20 June 2011 by the Vice President of the Republic of Indonesia with the launch of general national plan for road traffic safety RUNK LLAJ.

In 2013, President actually gave orders to the ministers of transportation, the governor and regent/mayor stakeholders throughout Indonesia to

Bambang Istiyanto is with the Politeknik Keselamatan Transportasi Jalan, Tegal, 52125, Central Java, Indonesia (e-mail: bambangistiyanto@pktj.ac.id; bambangistiyanto@gmail.com). implement road safety programs, as stated in Instruction of President of Republic Indonesia No. 4 Year 2013. The program is then in 2017 strengthened by the legality of the enactment of Government Regulation No. 37 of 2017 on Safety and Traffic and Road Transport. From this regulation, there are duties and responsibilities carried out by the district/city governments in Indonesia. The districts/municipal governments are required to prepare a Plan of Action for Safety (RAK) as a form of implementation of the National General Plan of Traffic Safety and Road Transport (RUNK-LLAJ). Implementation of the district level safety system contributes to the success of the national safety program.

In addition to the road transport safety action program in the decade of action for road safety 20102020 , by United Nation. This safety action is again reinforced in another progressive program, the Sustainable Development Goals in place of the Millennium Development Goals program that ends in 2015, as outlined in the Transforming Our World document: The 2030 Agenda for Sustainable Development published by the United Nations on global objectives to-III on the 6th global target "In Year 2020 reduces to half the number of global deaths and injuries from traffic accidents" and to the XI's global goal on the 2nd global target "In 2030, providing access to safe, affordable, accessible and sustainable for all, improving traffic safety, especially by expanding the reach of public transport, paying particular attention to the needs of those in vulnerable situations, women, children, persons with disabilities and parents.

The Government of Indonesia is one of the 193 heads of State and governments that have come to agree on this global development agenda. This is confirmed by the issuance of Presidential Regulation (PERPRES) number 59 of 2017 on the Implementation of the Achievement of Sustainable Development Objectives. In the perpres is ordered to the district/city government as the executor of achieving the goals and objectives. SDGs program is an affirmation to the government to focus more on the development targets in which road traffic safety program. A proper road traffic safety program should reduce the incidence and death of road traffic accidents.

The incidence of accidents in Indonesia in the highest provinces is in East Java Province of 5,929 cases and Central Java of 4,252. In East Java province the highest accident in Pasuruan Regency, the data for the last 5 years (2013-2017) the average increase in the number of accidents by $6.25 \%$ per year. With the details of the year 2013 as many as 638 events, in 2014 
as many as 679 events, in 2015 as many as 839 events, 2016 as many as 874 jobs, and in 2017 as many as 794 events. In Central Java Province the second largest accident number after East Java, where the death toll is 967 people, seriously injured 21 people and lightly injured 4,865 people so that the total casualty is 5,853 people. In Central Java Province, the highest incidence of accidents was in Banyumas District with 1,002 most cases of accidents in 2016 and in 2017 cases of accidents in Banyumas decreased to occupy the third position of 978 cases of accidents.

Taking that into account, and the tremendous impact of traffic accidents it is necessary to evaluate the implementation of the program. The implementation of the safety actions undertaken at the district level in Indonesia shall be carried out by the respective agencies concerned, in accordance with their respective duties and functions. Approaches that do work according to authority, not integrated with each other, there are even overlapping work between agencies. It is, necessary to evaluate the safety action plan in the district. In order for this action program to run optimally can reduce the incidence of accidents, death, and fatality rate of the victim.

\section{ROAD TRAFFIC SAFETY PROGRAMS (RTSP)}

\section{A. Component of RTSP}

Nationally, road traffic and transportation safety system is set up in the RUNK-LLAJ of Road Traffic safety system as stated in Government Regulation No 37 the Year 2017 on vision and mission, target, policy, strategy and national program. The national program includes the activities of the safety management system, the safer road, the safer vehicles, safer users, and post-crash response (PP, 2017).

The implementation of the national five (5) Pillars of Decade of Action for Road Safety Program is regulated in Instruction of President of Republic Indonesia No. 4 Year 2013 as the implementation of the resolution of the United Nations Convention No. 64/255 on 10 March 2010 on Improving Global Road Safety. The five-pillar program has an indicator of activities that must be undertaken by relevant ministries, governors and regents/mayors throughout Indonesia. The activities on Pillar I of Road Safety Management focus on road safety coordination and adjustment; emergency vehicle traffic protocol, road safety research, surveillance injury and the integrated information system, road safety funding, road safety partnership, public transport safety management system, and completion of road safety regulations. Pillar II focuses on safer road pavement / body, planning and implementation of safer road works, planning and implementation of road equipment, application of speed management, conducting the improvement of safer road-worthiness standard, safer road environment, and safer roadside activities. Pillar III focuses on implementation and improvement of periodic testing and type testing procedures, speed limit on vehicle, and handling of overloading vehicle scrapping, and setting the safety standards for public transport vehicle. Pillar IV focuses on vehicle operations compliance, driver's condition inspection, driver's health inspection, driving license test system's facility and infrastructure improvement, completion of driving license test procedure, driving schools technical coaching, handling of five (5) main risk factors plus, use of electronic law enforcement equipment, formal road safety education, and safety campaign. Pillar V, namely pre and post-accident handling focuses on preaccident management, post-accident management, assurance for accident victims that are treated in referral hospital, allocating some insurance premiums for road safety fund, pre and post-accident research for the victim (Perpres, 2013).

\section{B. Implementing Of RTSP}

In Indonesia the implementation of road traffic and transportation safety programs is carried out with activities as regulated in Government Regulation No. 37 of 2017 article 2, covering the activities of: Traffic Safety and Road Transportation (RTSP) planning, implementation and control of RTSP, public transport company safety system, traffic accidents and RTSP surveillance tool (PP, 2017). Along with other government development programs, the implementation of the RTSP program for district/municipality governments is emphasized in Regulation of President of Republic Indonesia No. 59 of 2017 on the Implementation of the Achievement of Sustainable Development Objectives.

The main target of RTSP program implementation is the decrease of accidental fatality rate and social cost as the impact of traffic accidents, for the purpose of achieving those targets; it needs implementation and control in RTSP management. The management of RTSP includes activities: the achievement of desired goals or outcomes, the implementation of direct actions in synergy among related institutions, and the support of authority over the function according to the role of each institution.

The implementation of RTSP in the districts is carried out by Local Transportation Agency, Public Works Agency, Development Planning Agency at SubNational Level, Resort Police of Republic Indonesia, and Health Agency who are members of the Road Traffic and Transportation Forum (FLLAJ). The FLLAJ was formed by a decree of the regent to the region with the above-mentioned institutions. The duties and responsibilities of each institution are regulated in the decree. In government affairs, there are two institutions that have a work unit of safety and accidents; Local Transportation Agency and the police resort in the organizational structure and governance work of government organizations.

\section{METHODS}

\section{A. Source of Data}

The highest numbers of accidents in Indonesia are in East and Central Java, while for the highest regency/city itself in East Java is located in Pasuruan 
Regency and for Central Java is in Banyumas Regency. The research sites are in these two districts, the variables of each pillar are identified and collected related to the implementation of the RTSP.

The program data collected at the implementing agencies appointed in the Presidential Instruction No. 4 of 2013 include: Regional Development Planning Agency, Public Works Department, Transportation Department, Police Resort (Polres), and Health Office at Pasuruan and Banyumas. The data collected on these offices then checked with implementation in the field, by conducting a traffic management and traffic survey on the roads that are prone to accidents.

\section{B. Evaluation}

Analysis of inventory data of RTSP implementation at Pasuruan and Banyumas Regency by using the binary system, score 1 if the regency implements the program and 0 if the regency doesn't, and then calculating all pillars using RTSP. The results of calculation later are made in the form of RTSP implementation percentage. The analysis is conducted using Microsoft Excel.

This research focused on RTSP implementation in accordance with Presidential Instruction No. 4 of 2013, with Pillar 1 performance of road safety management, Pillar 2 road safety, Pillar 3 vehicle safety, Pillar 4 user safety behavior, Pillar 5 post accident handling, and a recapitulation was also made for the entire pillars.

\section{Results And Discussion}

\section{A. Profile of Accident}

The accidents in Banyumas Regency are higher than Pasuruan Regency either from the incident, death, and minor injury. However, the number for serious injuries in Banyumas are higher than Pasuruan Regency, the detail information can be seen in table 1 below.

TABLE 1.

TRAFFIC ACCIDENT PROFILE IN 2015-2017

\begin{tabular}{ccccc}
\hline District & Profile & 2015 & 2016 & 2017 \\
\hline Pasuruan & Incident & 839 & 874 & 794 \\
& Died & 223 & 221 & 179 \\
& Serious Injuries & 26 & 153 & 97 \\
& Minor Injuries & 957 & 859 & 878 \\
Banyumas & Incident & 1056 & 1002 & 978 \\
& Died & 249 & 237 & 225 \\
& Serious & & & \\
& Injuries & 2 & 0 & 2 \\
& Minor Injuries & 1197 & 1100 & 1032 \\
\hline Data source: BPS, 2018 & & &
\end{tabular}

Table 1shows the traffic accident happened in Banyumas Regency with approximately 1.110 cases is higher than Pasuruan for 836 cases. The number of deaths in Pasuruan was 623 people in three years; lower than 771 in Banyumas Regency. While for serious injuries in Pasuruan in three years is higher by 276 people, while in Banyumas regency by 4 people.
Thus, there is a decrease for the severity of traffic accidents in Pasuruan, while in Banyumas there was no significant decrease, tends to stagnant. More complete information can be seen in Fig 1.

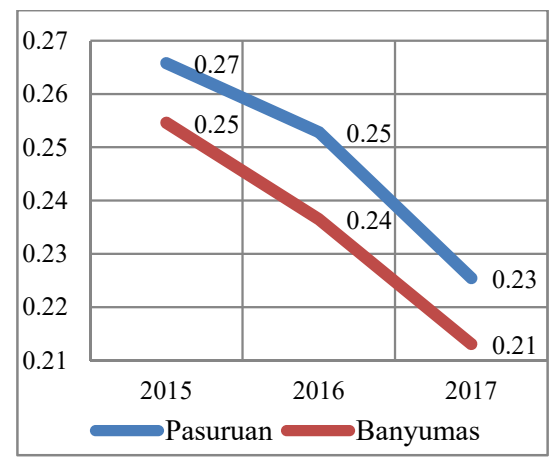

Fig. 1. Figure of Fatality Traffic Accident

\section{B. Implementing RTSP}

Implementation of the RTSP in Pasuruan and Banyumas is carried out by stakeholders who are members of the Road Transportation Traffic Forum, formed by the Regent with members from Local Transportation Agency, Public Works Agency, and Development Planning Agency at Sub-National Level, Resort Police of Republic Indonesia, and Health Agency (Perpres, 2013). In RTSP, there are five main pillars that must be done by the Government of Pasuruan and Banyumas Regency in the action of decreasing the number of accidents. They are safety management system as pillar 1 , safer roads as pillar 2, safer vehicle as pillar 3, safer road users as pillar 4 and postaccident handling as pillar 5 . The evaluation is conducted by identifying each activity in RTSP that is done by the district government. The checklist for evaluation is in Appendix 1.

The program on pillar 1

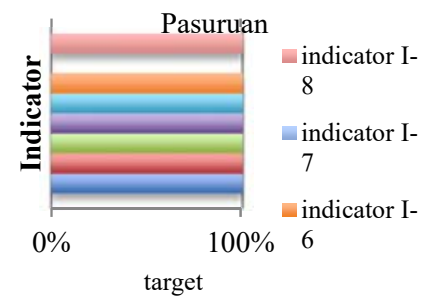
consists of 8 variables where variable 1 has 4 indicators, variable 2 has 2 indicators, variable 3 has 3 indicators, variable 4 has 5 indicators, variable 5 has 2 indicators, variable 6 has 2 indicators, variable 7 has 2 indicators, and variable has 2 indicators. The results of evaluation of pillar 1 in Banyumas and Pasuruan Regency are shown in Fig. 2.

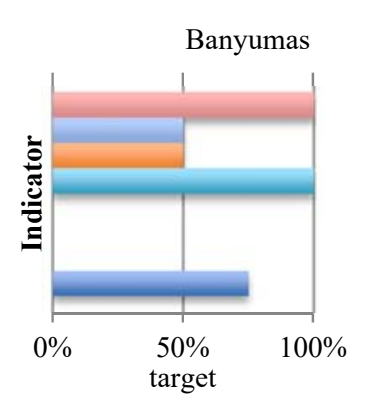

\begin{tabular}{ll} 
& Fig. 2. \\
$\square$ indicator I-8 & Figure of \\
$\square$ indicator I-7 & Performan \\
ce of \\
$\square$ indicator I-6 & Pillar 1 \\
$\square$ indicator I-5 & Safety \\
Managem \\
ent \\
indicator I-4 & System \\
$\square$ indicator I-3 & \multicolumn{2}{c}{ From } \\
$\square$ indicator I 2 & the Fig.
\end{tabular}

2 , it can be seen that the safety management system in Pasuruan Regency is better by having 7 variables conducted. While Banyumas Regency only carried out 
5 variables with variable I indicator 6 and indicator 7 are done by $50 \%$.

The program on pillar 2 consists of 7 variables where variable 1 has 5 indicators, variables 2 has 7 indicators, variable 3 has 3 indicators, variable 4 has 4 indicators, variable 5 has 3 indicators, variable 6 has 3 indicators, and variable 7 has 1 indicator. The results of evaluation of pillar 2 in Banyumas and Pasuruan Regency are shown in Fig. 3.
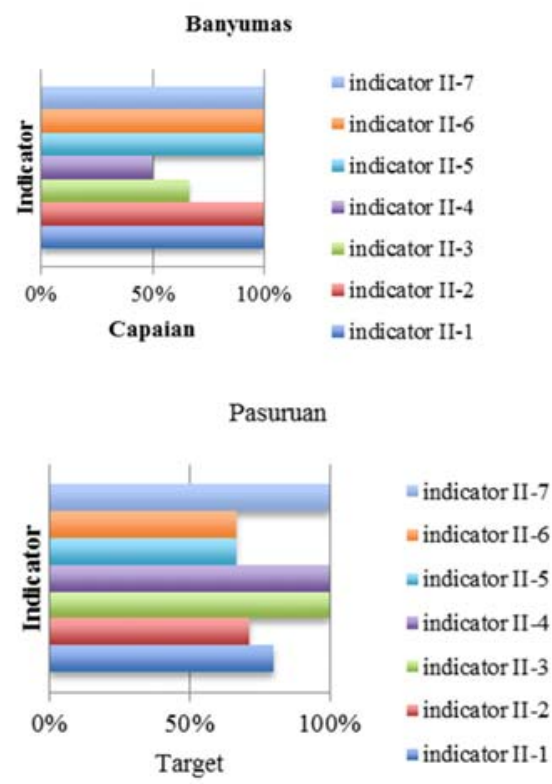

Fig. 3. Figure of Performance Pillar 2 Safer Road

Program on pillar 3 consists of 5 variables, which variable 1 there are 4 indicators, variable. The program on pillar 3 consists of 5 variables where variable 1 has 4 indicators, variable 2 has 1 indicator, variable 3 has 5 indicators, variable 4 has 1 indicator, and variable 5 has 1 indicator. The results of evaluation of pillar 3 in Banyumas and Pasuruan Regency are shown in Fig.4.



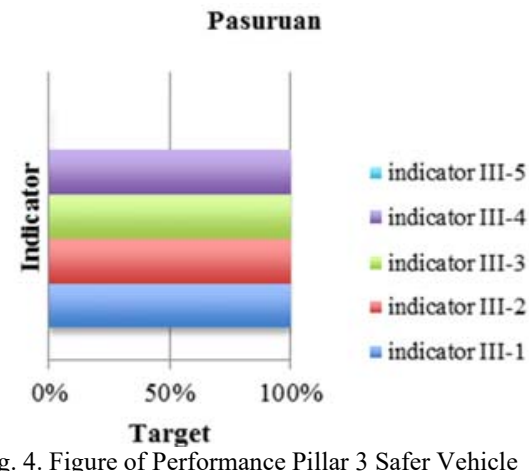

Program on pillar 4 consists of 10 variables where variable 1 has 4 indicators, variables 2 has 2 indicators, variable 3 has 1 indicator, variable 4 has 3 indicators, variable 5 as 1 indicator, variable 6 has 4 indicators, variable 7 has 6 indicators, variable 8 has 1 indicator, variable 9 has 1 indicator, and variable 10 has 1 indicator. The results of evaluation of pillar 4 in Kabupaten Banyumas and Pasuruan are shown in Fig 5.

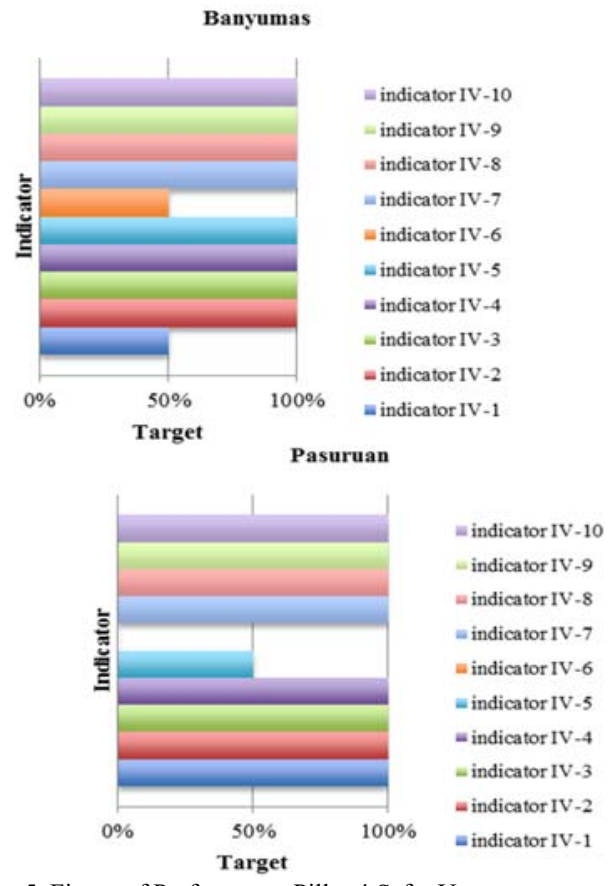

Fig. 5. Figure of Performance Pillar 4 Safer User

Program on pillar 5 consists of 5 variables where variable 1 has 2 indicators, variable 2 has 1 indicator, variable 3 has 2 indicators, variable 4 has 1 indicator, and variable 5 has 1 indicator. The results of evaluation of pillar 5 in Kabupaten Banyumas and Pasuruan are shown in Fig.6. 


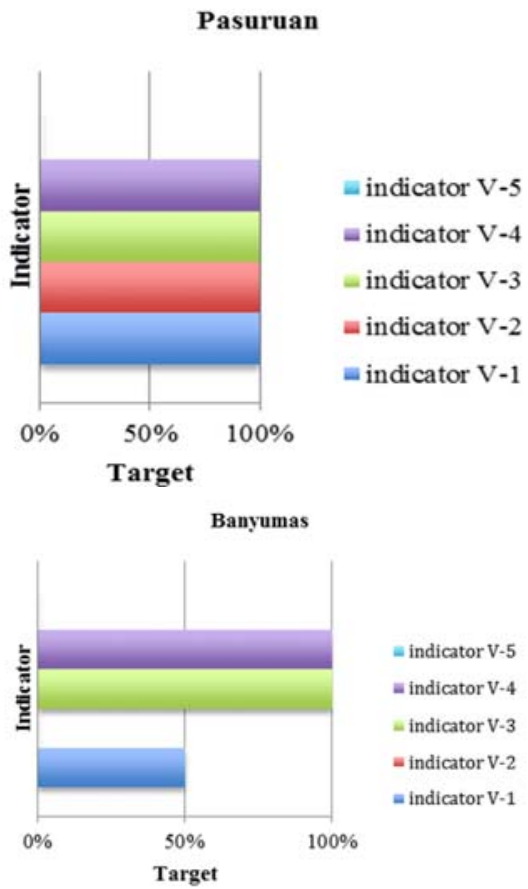

Fig. 6. Figure of Performance Pillar 5 Post Crash

Recapitulation of the achievement of 5 pillars in RTSP for Banyumas and Pasuruan Regency can be seen in Fig.7.

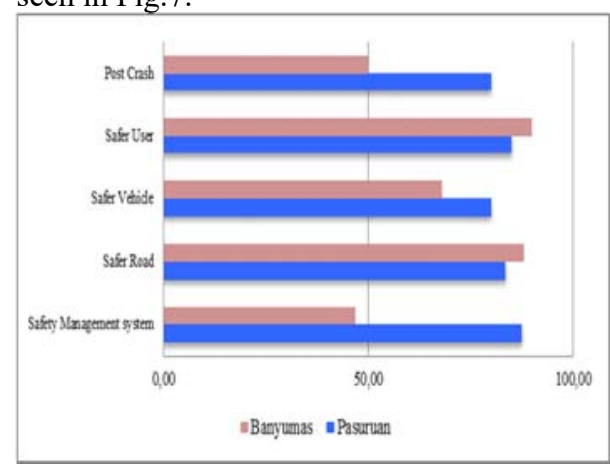

Fig. 7. Figure of Performance 5 Pillar RTSP

\section{CONCLUSIONS}

The performance of 5 pillars of RTSP in two districts shows that all programs have been implemented, seen in the safety management system pillar 1 in Pasuruan Regency at $87.50 \%$ and for Banyumas regency $46.88 \%$, Safer road pillar 2 in Pasuruan Regency at $85 \%$ and Banyumas Regency is $88.10 \%$, pillar 3 vehicle safer in Pasuruan district is $80 \%$ and in Banyumas Regency is $68 \%$, pillar 4 user safer in Pasuruan Regency is $80 \%$ and Banyumas Regency is $90 \%$, pillar 5 poses a response crash in the Regency Pasuruan is $80 \%$ and in Banyumas Regency is $50 \%$.

From the evaluation of the program implementation showed that the Pasuruan and Banyumas District Governments had implemented 5 RTSP pillars, but it did not significantly reduce the incidence of accidents and fatality rates. This condition is possible because the program implemented is the authority of the central government, while for programs that are directly related to the improvement of safety indicators at the district level have not been done optimally.

This study is still based on national indicators and has not conformed to the RTSP where the variables are required by the district. Thus, this research should be improved with further research related to the RTSP that fit the needs of the district. Any suggestions and further thoughts for deeper study would be highly appreciated. Eventually, many thanks to everyone involving in collecting data and writing this paper.

\section{REFERENCES}

[1]. Badan Pusat Statistik (BPS), Statistic Indonesia, Badan Pusat Statistik. Jakarta, Indonesia. 2018.

[2]. Presiden Republik Indonesia (Perpres), Instruksi Presiden Nomor 4 Tahun 2013 Tentang Program Dekade Aksi Keselamatan Jalan. Jakarta, Indonesia, 2013.

[3]. Pemerintah Republik Indonesia (PP), Peraturan Pemerintah Republik Indonesia Nomor 37 Tahun 2017 Tentang Keselamatan Lalu Lintas dan Angkutan Jalan. Lembaran Negara Republik Indonesia Nomor 205. Jakarta, 2017.

\section{APENDIX 1}

The index is based on both a content analysis approach and a binary methodology (report/no report) with only the items, which have been considered pertinent and not redundant. For instance, the use of random breath testing and/or police checkpoints in the national drink driving law is included in the enforcement index. The value of our index per pillar ranges from 0 to $100 \%$, and it takes into account whether there is total, partial or non-implementation of certain actions. In addition, when possible, the selfrated level of enforcement is included. The indicators that are included in the calculation of the RSM index and the weightings and values assigned to these indicators are summarized in the table below. 


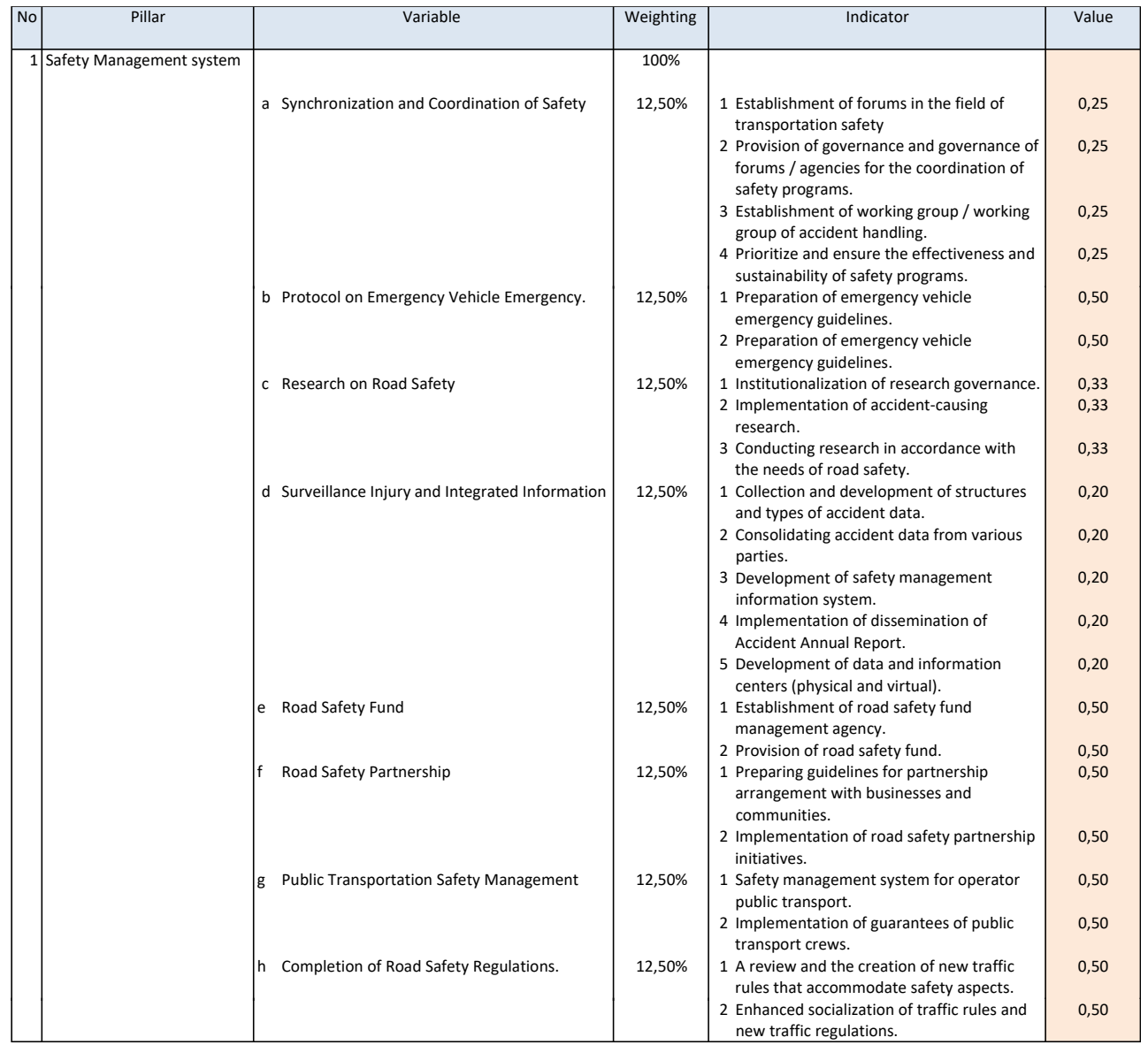

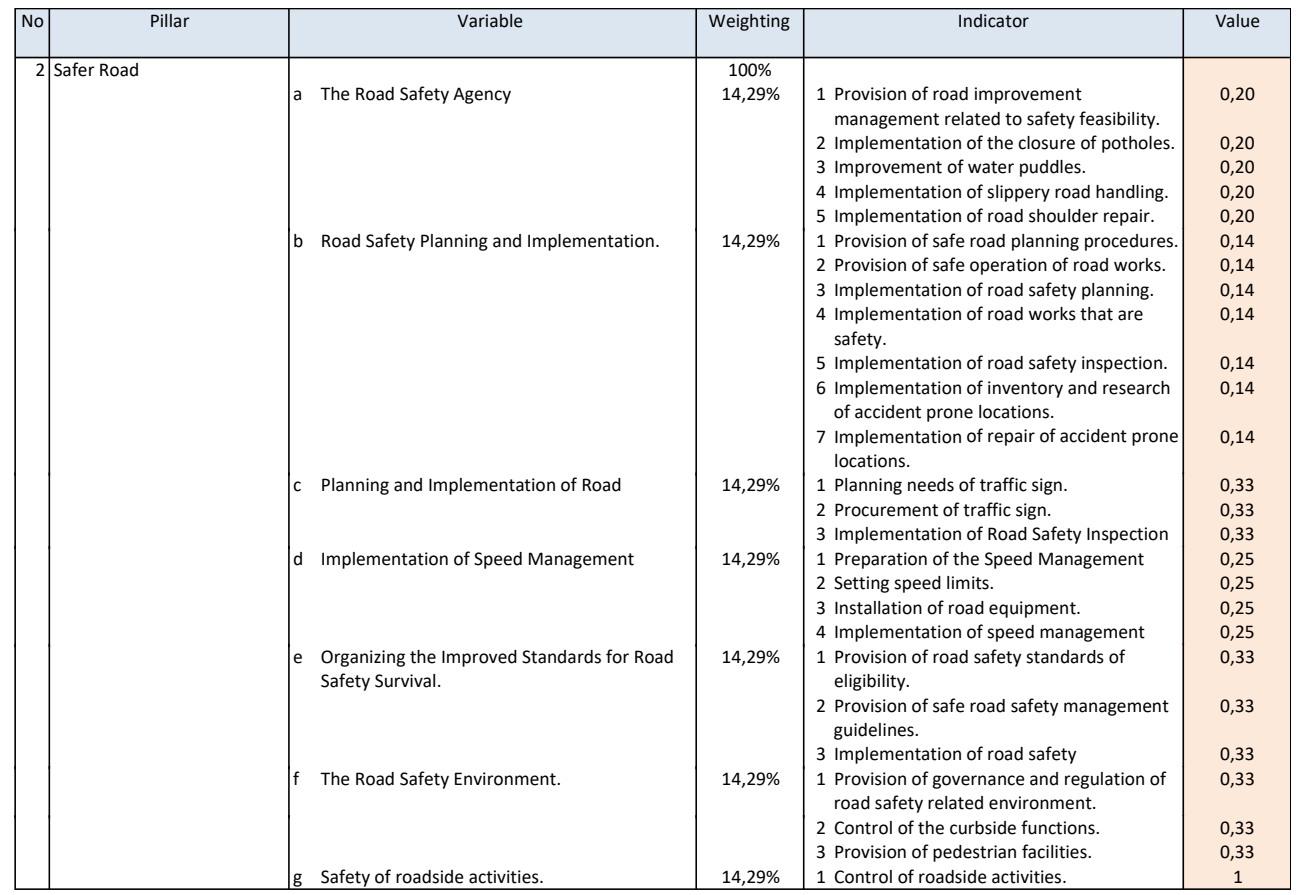




\begin{tabular}{|c|c|c|c|c|c|c|}
\hline No & Pillar & & Variable & Weighting & Indicator & Value \\
\hline & Safer Vehicle & b & $\begin{array}{l}\text { Implementation and Repair of Periodic Vehicle } \\
\text { Inspection Procedures and Type Test. } \\
\text { Speed Limit on Vehicles. } \\
\text { Control of vehicle overloading. } \\
\text { Removal of the Vehicle (Scrapping). } \\
\text { Implemention of the Standard of Safety for } \\
\text { Public Vehicle. }\end{array}$ & $\begin{array}{l}20 \% \\
20 \%\end{array}$ & $\begin{array}{l}1 \text { Completion of procedures and periodic } \\
\text { vehicle inspection manuals and type tests. } \\
2 \text { Development of techno-based testing } \\
3 \text { Implementation of periodic testing system } \\
\text { evaluation and type test. } \\
4 \text { Implementation of vehicle inspection on } \\
\text { the road. } \\
1 \text { Speed limitations on vehicles. } \\
1 \text { Organizing community participation in Say } \\
\text { No to Overloading movement. } \\
2 \text { Implementation of good governance } \\
3 \text { Completion of weighbridge function. } \\
4 \text { Implementation of Intelligent } \\
\text { Transportation System (ITS) in the field of } \\
\text { goods transport. } \\
5 \text { Arrangement of the dimensions and } \\
\text { volume of haulage (mixers, tubs, tanks) on } \\
\text { freight vehicles in the type of motor } \\
\text { vehicle test. } \\
1 \text { Removal of Vehicle (Scrapping) } \\
1 \text { Determination of the Standard of Public } \\
\text { Vehicle Safety. }\end{array}$ & $\begin{array}{c}0,25 \\
0,25 \\
0,25 \\
0,25 \\
1 \\
0,20 \\
0,20 \\
0,20 \\
0,20\end{array}$ \\
\hline
\end{tabular}

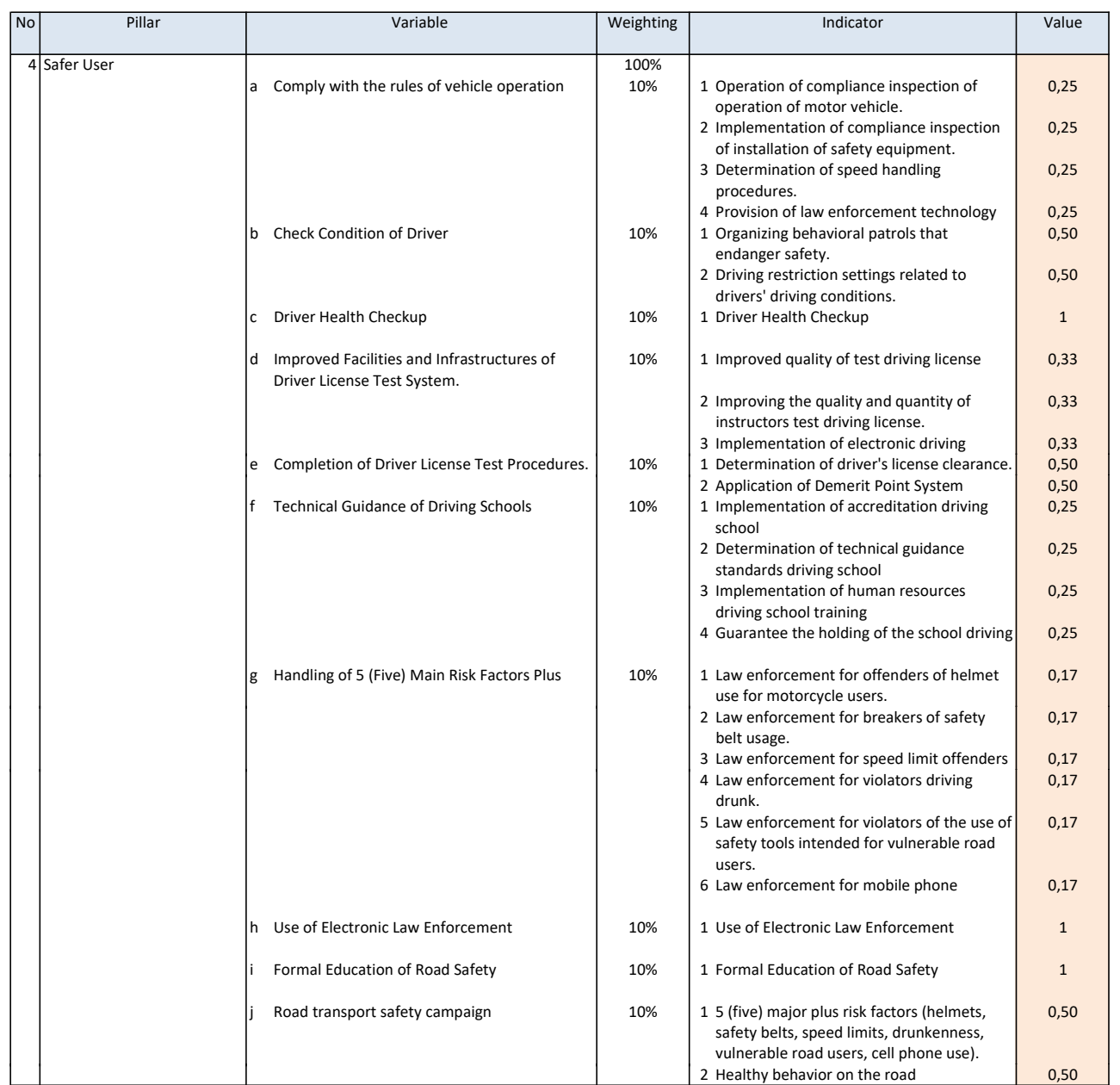




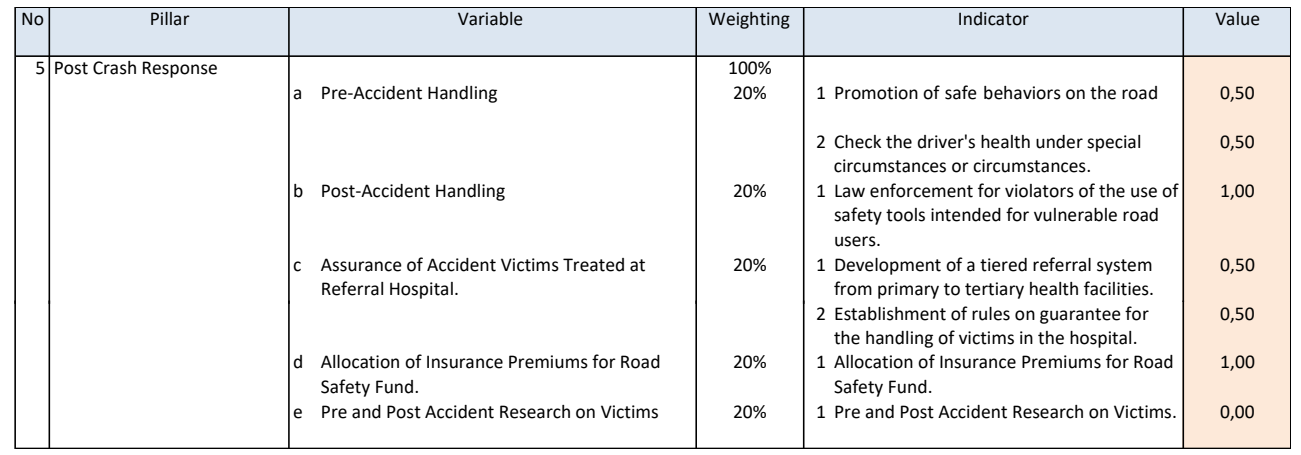

